\title{
Exploring the effect of ICT solutions on GHG emissions in 2030
}

\author{
Jens Malmodin, Pernilla Bergmark \\ Ericsson Research, Ericsson AB \\ Stockholm, Sweden \\ jens.malmodin@ericsson.com, pernilla.bergmark@ericsson.com
}

\begin{abstract}
Information and Communication Technologies (ICT) are expected to have a great potential to reduce the GHG emissions across society, however limited data on actual reductions have been published so far. Based on available data on real GHG emission reductions realized by different ICT solutions, this paper explores the possible reductions globally within a 2030 timeframe. An average of the future scenarios for 2030 made by United Nation's Intergovernmental Panel on Climate Change (IPCC) has been modified by applying GHG reduction potentials for different ICT solutions in sectors like energy, buildings, travel and transport. In addition, a comparison with the SMARer2020 forecast is included. The results indicates a total GHG emission reduction potential due to the studied ICT solutions of about 8 Gtonnes $\mathrm{CO}_{2} \mathrm{e}$ or $12 \%$ of the global GHG emissions in 2030 in a high reduction potential scenario, and 4 Gtonnes $\mathrm{CO}_{2} \mathrm{e}$ in 2030 or $6 \%$ in a medium reduction potential scenario. If also estimated potentials related to agriculture are added based on the SMARTer 2020 study the potentials increase to 10 Gtonnes $\mathrm{CO}_{2} \mathrm{e}(15 \%)$ and 5 Gtonnes $\mathrm{CO}_{2} \mathrm{e}(8 \%)$ respectively. This corresponds to reduction potentials for the different ICT solution categories of 1 to $4 \%$.
\end{abstract}

Keywords-ICT, ICT solution, networked society, enabling potential, macro-level, GHG emissions reductions

\section{INTRODUCTION}

The increasing global greenhouse gas (GHG) emissions are a serious problem. According to United Nation's Intergovernmental Panel on Climate Change (IPCC) the global GHG emissions need to be reduced by $40-70 \%$ in 2050 compared to 2010 in order to stay below the $2{ }^{\circ} \mathrm{C}$ increase in global average temperature, as indicated in Figure 1 [1].

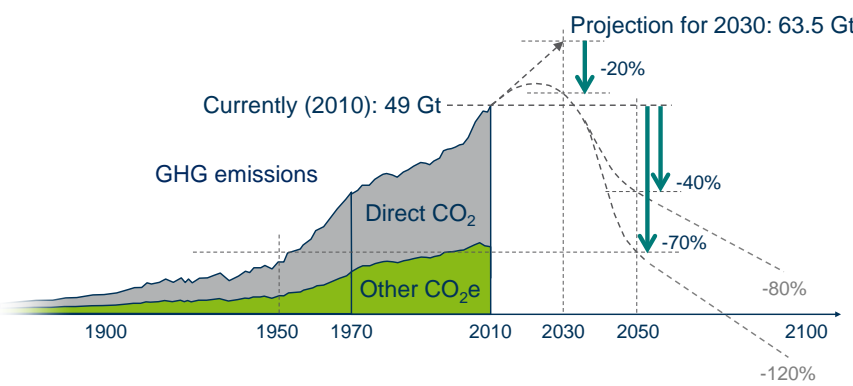

Figure 1 Global GHG emissions until 2010 and future estimates including required levels to keep the global temperature average increase below $2^{\circ} \mathrm{C}$ (based on [1]-[6]).
There have been several attempts to estimate the GHG emission reduction potential in the future, for instance by the Global e-Sustinabaility Initiaitve (GeSI) and within the European Union, describing the reduction potential from ICT until 2020 [7], [8]. In 2014, Ericsson decided to make an estimate for 2030, based on published data for specific ICT solutions. The year 2030 was chosen as the target as it is considered far enough ahead to allow for transformational changes to happen.

Building on our previous work [9] on modelling of global GHG emissions related to ICT and data collection for different services, this paper describes the methodology (section II), data and references used for both baseline per industry sector and enablement potential calculations (section III and IV), as well as the assumptions made for the calculations (section III) and results and conclusions (section V and VII). Estimations include the potential specifically related to the described ICT solutions. Thus, there may be other existing or future ICT solutions allowing for additional reductions in GHG emissions. On the other hand, published data do not often consider the footprint of ICT itself, so in these cases the footprint of the ICT solution has to be extracted from the positive effect from it. Further discussions include the realization of the enablement potential and a comparison to the SMARTer 2020 report [7] (section VII).

\section{METHOD}

The main steps to estimate the global potential reductions in GHG emissions from the studied ICT solutions were (i) Creating a model of future GHG emissions that can be reduced by ICT solutions on a basic (e.g. energy) and sector level using an end-user perspective; (ii) Gathering data on GHG emissions reductions due to ICT solutions applying a life cycle perspective to the extent possible, preferably based on measurements, otherwise calculations or estimates for the future; (iii) Defining relevant scenarios and setting reduction factors for the different ICT solutions; (iv) For each scenario, and applicable solutions and reduction factors, calculating the potential reductions of the global GHG emissions for the assessed year; and (v) Avoiding double-counting by multiplying reductions that address the same emissions. This is done both within and between sectors. 


\section{GHG EMISSIONS IN 2030}

\section{A. Overview of GHG emissions distribution 2000-2010}

When studying the impacts of ICT a sectorial approach seems reasonable as emissions data are available on a sector level - and as the use of ICT could be more easily understood at this level. A global GHG emission model developed by the World Resources Institute (WRI) [3]-[5] was used to understand how emissions have been distributed historically between industry sectors (see table I) and to estimate the future baseline emissions.

TABLE I. GLOBAL GHG EMISSIONS IN MTONNES $\mathrm{CO}_{2}$ E FOR THE MAIN SECTORS 2000, 2005 AND 2010

\begin{tabular}{|l|c|c|c|}
\hline & $\mathbf{2 0 0 0}$ & $\mathbf{2 0 0 5}$ & $\mathbf{2 0 1 0}$ \\
\hline Industry: Energy & 3996 & 4389 & 6464 \\
\hline Industry: Raw materials & 5578 & 6339 & 8080 \\
\hline Industry: Other & 4787 & 6162 & 6170 \\
\hline Buildings & 6369 & 7359 & 8766 \\
\hline Transports and travel & 5745 & 6339 & 7150 \\
\hline Agriculture & 6203 & 6738 & 5534 \\
\hline Land use & 7577 & 5408 & 5044 \\
\hline Waste & 1499 & 1419 & 1420 \\
\hline Total & $\mathbf{4 1 7 5 5}$ & $\mathbf{4 4 ~ 1 5 3}$ & $\mathbf{4 8 6 2 9}$ \\
\hline
\end{tabular}

B. Allocation of global GHG emissions and effects to enduse sectors based on [3]-[5]

One challenge in this study was to allocate life cycle emissions from basic resources like fuel, energy and raw materials to end-use sectors.

Figure 2 shows the global GHG emissions in 2010 (including both GHG emissions and other effects with a global warming potential such as deforestation) of the seven end-use sectors (a) and how the emissions from primary resources (c) have been allocated to these end-use sectors in our model.

Part (c) should be read from the bottom and upwards. Firstly, applicable parts of the emissions related to primary fuels are allocated to electricity, other energy (representing district heating supplied as hot water or steam) and raw materials production processes (c). In a next step the four primary resources (fuel, electricity, other energy and raw materials) are re-distributed into the intermediate categories of fuel supply, raw materials supply and energy supply (b). As an example, part of the electricity is combined with other energy and forms energy supply. Finally, the intermediate categories end up as embodied emissions in the end-use sectors.

Buildings, transports and travel are further divided into subsectors primarily based on WRI but also other sources ${ }^{1}$.

The resulting addressable emissions are shown in table IX. The reason for this sub-division of sectors is to better map the ICT solutions towards the addressable emissions.

${ }^{1}$ The available space for this paper does not allow for details to be provided but the author would be happy to share this information.

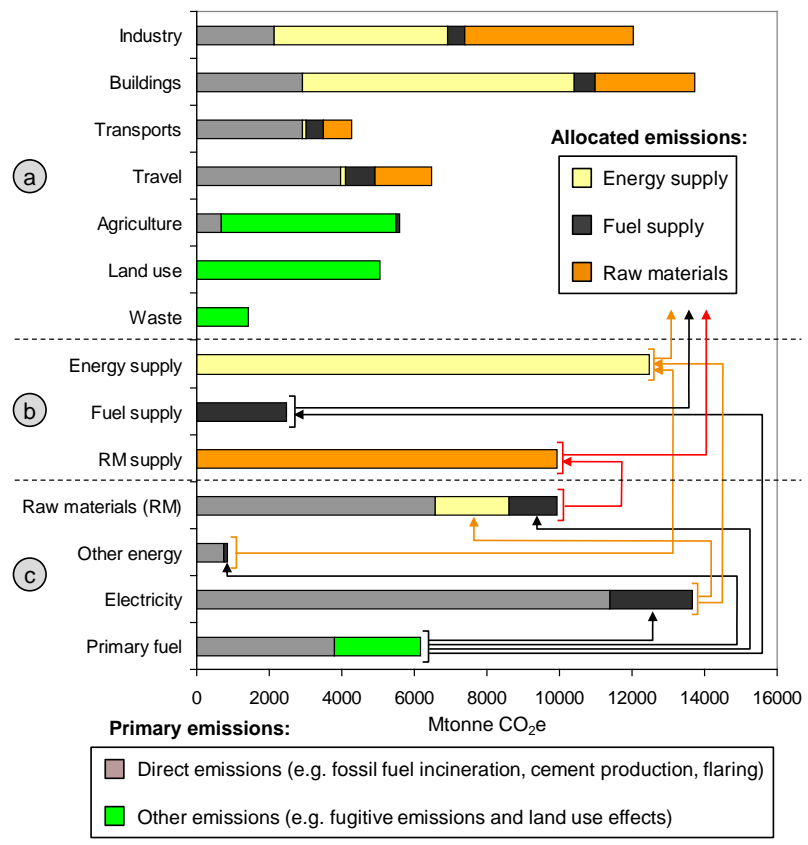

Figure 2 Allocation of global GHG emissions in 2010 to seven end use sectors

\section{Global GHG emissions and effects prognosis to 2030}

IPCC estimates that the global GHG emissions and effects will be in the range of $49-77 \mathrm{Gt} \mathrm{CO}_{2} \mathrm{e}$ in 2030 according to their six main scenarios presented in IPCCs $4^{\text {th }}$ assessment report (AR4) [2]. These main scenarios are referred to as baseline scenarios in the recently released fifth assessment report, which also includes a number of mitigation scenarios that have not been further used here [1].

In this study we have used the average value of the six scenarios, 63.5 Gtonnes $\mathrm{CO}_{2} \mathrm{e}$, as a baseline. This corresponds to an increase of $22 \mathrm{Gt} \mathrm{CO}_{2} \mathrm{e}$ compared to year 2000 emissions as presented in section III.A. Combining the average value from IPCC [2] with the sector information from WRI [3]-[5], GHG emissions for each main sector are projected to grow as shown in Table 2.

TABLE II. PROGNOSIS FOR FUTURE GLOBAL GHG EMISSION GROWTH 2010-2030 PER SECTOR

\begin{tabular}{|c|c|c|c|}
\hline Sector & $\begin{array}{c}\text { Yearly } \\
\text { increas } \\
\text { e }+ \\
(\%) \\
\end{array}$ & $\begin{array}{l}2030 \\
{[\mathbf{M t}]}\end{array}$ & $\begin{array}{l}\text { This study } \\
2030 \text { [Mt] }\end{array}$ \\
\hline Industry & & & 14790 \\
\hline - Raw materials & $+0.6 \%$ & $9000 * * *$ & \multirow{2}{*}{$\begin{array}{l}\text { Allocated to buildings, } \\
\text { travel, transports, industry } \\
\text { and agriculture }\end{array}$} \\
\hline - Energy & $+1.1 \%$ & $8000^{* * *}$ & \\
\hline - Other & $+1 \%$ & $7500 * * *$ & Allocated to industry \\
\hline Buildings & $+2.5 \%$ & $12300 * *$ & 17220 \\
\hline Transports and travel & $+2 \%$ & $10600 *$ & $\begin{array}{c}\text { Split between travel and } \\
\text { transports: }\end{array}$ \\
\hline - Transports & & & 5680 \\
\hline - Travel & & & 9490 \\
\hline Agriculture & $+2 \%$ & $8300 *$ & 8430 \\
\hline
\end{tabular}




\begin{tabular}{|l|c|c|c|}
\hline \multicolumn{1}{|c|}{ Sector } & $\begin{array}{c}\text { Yearly } \\
\text { increas } \\
\text { e + } \\
\mathbf{( \% )}\end{array}$ & $\begin{array}{c}\mathbf{2 0 3 0} \\
{[\mathbf{M t}]}\end{array}$ & $\begin{array}{c}\text { This study } \\
\mathbf{2 0 3 0}[\mathbf{M t}]\end{array}$ \\
\hline Land use & $+0.7 \%$ & $5800^{*}$ & 5800 \\
\hline Waste & $+2 \%$ & $2100^{*}$ & 2100 \\
\hline Total & $+1.4 \%$ & $63500^{*}$ & 63500 \\
\hline
\end{tabular}

\section{A. Smart grid}

The smart grid can be defined in different ways; often the concept includes integration of renewable energy sources, power load balancing and power grid optimization. Demand management and time-of-day pricing, as well as a possible reduction of transmission and distribution losses are other features. ICT solutions are needed for the smart grid, but not all potential GHG emissions reductions are due to ICT.

So far, mainly smart metering has been implemented. Smart meters could lead to lower energy use by enabling visibility and awareness of use patterns as well as more sophisticated billing and could be implemented through automated systems or behavioral changes.

\section{TABLE III. BACKGROUND DATA FOR SMART GRID} better with the WRI data for year 2000-2010 extrapolated to 2030 (see Buildings in column 4 in Table II). These emissions have instead been added to the industry sector. Thus the 2030 estimate for the industry sector (See Industry in column 4 in Table II) takes into account extrapolation of emissions estimated up to 2010 by WRI [5] and EcoFys [13] plus 2000 Mtonnes reallocated from buildings. In the present study (column 5) building emissions are assumed to be higher than in the combined IPCC/WRI projections (column 4) due to the allocation of life cycle emissions of basic resources to the enduse sectors, as described in III.B.

Comparing our model (column 5) and the combined IPCC/WRI projections (column 4) in Table II, our model uses the same sector distribution of GHG emissions as WRI [5], with two exceptions. Firstly, the GHG emissions related to energy and raw materials have been allocated to the sectors that use them. Secondly, the travel and transports sector has been divided into two separate parts.

Table I and II indicate that the total emissions for each sector increases over time and the distribution of overall emissions between sectors change somewhat.

\section{Main assumptions for the 2030 baseline}

The main assumption in the study is that the relative share of GHG emissions for the different parts of the end-use sectors (such as residential buildings and commercial buildings for Buildings) remains the same in 2030. It is also assumed that the share of embodied emissions remains the same.

IPCC takes into account improvements in energy generation in some scenarios. To what extent this includes measures that are enabled by ICT is not known. Consequently, some IPCC scenarios may contain a hidden additional potential to be associated with ICT. Alternatively, this may instead be seen as the estimated ICT potential but potentially including double-counting towards the baseline. This cannot be resolved due to lack of data, and adds to the overall uncertainties.

\section{ICT SOLUTIONS}

This section describes the different ICT solutions categories and gives the background data for the GHG emissions reductions potentials. The scenarios and the potentials used for the scenarios are shown in section $\mathrm{V}$.

\begin{tabular}{|l|l|}
\hline Smart metering, [10]: & $\begin{array}{l}\text { Key research findings: Saving from direct and } \\
\text { indirect feedback can range from 3-15\% and 0- } \\
\text { 10\% respectively. Specific customers examples: } \\
\text { 6.5\% average energy reduction due to in-home } \\
\text { displays and Home Area Network devices } \\
\text { respectively; and 2\% reduction due to online } \\
\text { feedback of historical data and monthly online } \\
\text { reports respectively (BC Hydro) }\end{array}$ \\
\hline Smart metering, [11] & $\begin{array}{l}\text { Residential electricity savings from real-time } \\
\text { feedback in nine pilots reviewed ranged from 0 } \\
\text { to 19.5\%, with average savings of 3.8\%. }\end{array}$ \\
\hline Smart metering, [12] & $\begin{array}{l}\text { 6\% electricity reduction shown for 500 000 } \\
\text { Korean households, 3\% estimated for the country }\end{array}$ \\
\hline $\begin{array}{l}\text { Renewable energy } \\
\text { solutions, [13] }\end{array}$ & $\begin{array}{l}\text { 2020 impact ranges from a 2\% to 7\% increase in } \\
\text { the share of the renewable energy solutions in } \\
\text { electricity generation due to ICT. }\end{array}$ \\
\hline $\begin{array}{l}\text { Demand management } \\
\text { potential, [7] }\end{array}$ & $\begin{array}{l}\text { Reduction factor 4\% applicable to 0.24 of 11.8 } \\
\text { Gtonnes global GHG emissions }\end{array}$ \\
\hline $\begin{array}{l}\text { Time-of-day pricing } \\
\text { potential, [7] }\end{array}$ & $\begin{array}{l}\text { Reduction factor 1\% applicable to an unknown } \\
\text { share of 11.8 Gtonnes global GHG emissions }\end{array}$ \\
\hline $\begin{array}{l}\text { Power load balancing } \\
\text { potential, [7] }\end{array}$ & $\begin{array}{l}\text { Reduction factor 60\% applicable to 0.24 of } 11.8 \\
\text { Gtonnes global GHG emissions }\end{array}$ \\
\hline $\begin{array}{l}\text { Power grid optimizat- } \\
\text { ion potential, [7] }\end{array}$ & $\begin{array}{l}\text { Reduction factor 30\% applicable to 1.1 of 11.8 } \\
\text { Gtonnes global GHG emissions }\end{array}$ \\
\hline $\begin{array}{l}\text { Virtual power plant } \\
\text { potential, [7] }\end{array}$ & $\begin{array}{l}\text { Reduction factor 26\% applicable to 0.14 of 11.8 } \\
\text { Gtonnes global GHG emissions }\end{array}$ \\
\hline $\begin{array}{l}\text { Increased renewable } \\
\text { energy sources } \\
\text { potential [14] }\end{array}$ & $\begin{array}{l}\text { This opportunity could reduce Australia's total } \\
\text { carbon emissions by 2.0\% per annum (11.3 } \\
\text { MtCO } 2 \text { e) }\end{array}$ \\
\hline$R$
\end{tabular}

\section{B. Smart buildings}

In this category, solutions for automated heating, ventilation and air conditioning (HVAC) systems as well as light control, building management and building auditing are included. Also included are solutions related to the smart grid like voltage optimization and local integration of renewable energy sources. Not included in this category are reductions related to smart electricity meters, which have been allocated to the Smart grid category, section IV.A.

\section{TABLE IV. BACKGROUND DATA FOR SMART BUILDINGS}

\begin{tabular}{|l|l|}
\hline Home energy & 1 billion kWh energy reduction estimated for \\
management systems, & Korean households based on an assumption from \\
T12] & $\begin{array}{l}\text { Telstra regarding a } 50 \% \text { reduction in of standby } \\
\text { power and electricity loss when implementing }\end{array}$ \\
\hline
\end{tabular}




\begin{tabular}{|l|l|}
\hline & home energy management systems \\
\hline $\begin{array}{l}\text { Smart building } \\
\text { management potential, } \\
\text { [7] }\end{array}$ & $\begin{array}{l}\text { 6\% energy reduction potential (derived from an } \\
\text { absolute number divided by total number of } \\
\text { buildings) }\end{array}$ \\
\hline $\begin{array}{l}\text { Building management } \\
\text { potential, [19] }\end{array}$ & $5-40 \%$ reduced energy consumption in buildings \\
\hline $\begin{array}{l}\text { Intelligent heating } \\
\text { potential, [20] }\end{array}$ & Potential for ICT to save 15\% of energy in 2030 \\
\hline $\begin{array}{l}\text { Intelligent heating } \\
\text { potential, [21] }\end{array}$ & $\begin{array}{l}\text { Improved heating and cooling control in } \\
\text { buildings can provide 10-15\% savings. }\end{array}$ \\
\hline Control HVAC, [22] & $\begin{array}{l}\text { 25\% potential energy reduction due to space and } \\
\text { hot water controls and appliances, lighting and } \\
\text { heating systems. Lifestyle change would have the } \\
\text { highest impact corresponding to 49\% reduction.. }\end{array}$ \\
\hline $\begin{array}{l}\text { Remote appliance } \\
\text { power management } \\
\text { potential, [14] }\end{array}$ & $\begin{array}{l}\text { Assumption that remote appliance power } \\
\text { management can reduce related stand-by } \\
\text { emissions by 50\%. }\end{array}$ \\
\hline $\begin{array}{l}\text { Context aware power } \\
\text { management } \\
\text { potential, [14] }\end{array}$ & $\begin{array}{l}\text { Assumption that context aware power } \\
\text { management can reduce orphaned energy } \\
\text { emissions by 50\% in one-third of Australian } \\
\text { homes and commercial buildings. Assumed that } \\
\text { 15\% of overall energy is orphaned in residential } \\
\text { and commercial buildings. }\end{array}$ \\
\hline
\end{tabular}

\section{Smart transport}

The Smart transport solutions taken into account in this study include route optimization and fleet management which both lead to reductions in fuel use for road transport, mainly for trucks. Another type of solution deals with shifting transport modes, for instance from truck and air transports to train or ship transports. In this case ICT enables efficient logistics that allows for optimized transport time etc.

Also Smart street lights could be allocated to this category. However, such solutions have not been included in this study as further detailed in section $\mathrm{V}$.

\section{TABLE V. BACKGROUND DATA FOR SMART TRANSPORTS}

\begin{tabular}{|l|l|}
\hline $\begin{array}{l}\text { Fleet management, } \\
\text { 23] }\end{array}$ & $\begin{array}{l}165 \text { 000 fewer miles driven for entire fleet of 300 } \\
\text { vehicles in California, USA, over 6 months. } \\
\text { (Verizon) }\end{array}$ \\
\hline $\begin{array}{l}\text { Fleet management, } \\
{[24]}\end{array}$ & $\begin{array}{l}\text { 23\% reduction of fuel costs over three years for } \\
30 \text { 000 vehicles (Vodafone) }\end{array}$ \\
\hline $\begin{array}{l}\text { Route optimization, } \\
\text { [25] }\end{array}$ & $\begin{array}{l}15 \% \text { reduction in travelled miles and 8\% in } \\
\text { average route in a German pilot study (DHL) }\end{array}$ \\
\hline $\begin{array}{l}\text { Route optimization, } \\
\text { [26] }\end{array}$ & $\begin{array}{l}\text { Reduction of 41500 liter fuels for 380 cars in } \\
\text { Slovenia, estimation of -10\% reduced fuel } \\
(\sim 50 \text { 000 l) for 300 cars in Macedonia (DT) }\end{array}$ \\
\hline $\begin{array}{l}\text { Connected public } \\
\text { waste bins, [27] }\end{array}$ & $\begin{array}{l}30 \text { tonnes (18\%) CO2 reduction compared to the } \\
\text { year before, corresponding to 373 car trips } \\
\text { Groningen, Netherlands }\end{array}$ \\
\hline $\begin{array}{l}\text { Real-time Freight } \\
\text { Management potential, } \\
{[14]}\end{array}$ & $\begin{array}{l}\text { Assumption that real-time fleet management } \\
\text { increases Australian payload capacity factors } \\
\text { equivalent to 12\% reduction in unladed distance. }\end{array}$ \\
\hline $\begin{array}{l}\text { Improved driver } \\
\text { performance potential, } \\
{[14]}\end{array}$ & $\begin{array}{l}\text { Assumption that ICT enables more efficient } \\
\text { driving and more efficient vehicle performance } \\
\text { by 10\% in nation-wide Australia }\end{array}$ \\
\hline $\begin{array}{l}\text { Dematerialization } \\
\text { leading to less freight } \\
\text { transport potential, } \\
\text { [20] }\end{array}$ & $\begin{array}{l}\text { Under the most optimistic assumptions }- \text { there } \\
\text { could be less increase in freight transport by } \\
\text { roughly 25\% due to ICT }\end{array}$ \\
\hline
\end{tabular}

Road network condition information

(both travel and

transport), [28]

\section{Smart work}

Most smart work solutions can reduce business travel and commuting which would affect both travelling patterns and the need for hotels and offices. Videoconference and teleconference solutions combined with the possibility to work outside the office are considered as smart work solutions. The solutions are to a large extent already available but are not utilized to their full potential.

\section{TABLE VI. BACKGROUND DATA FOR SMART WORK}

\begin{tabular}{|l|l|}
\hline $\begin{array}{l}\text { Smart work Telia, } \\
\text { [29] }\end{array}$ & $\begin{array}{l}\text { The direct CO2 emissions excluding infrastructure } \\
\text { have been reduced from about 3.2 ton to 1.9 ton, a } \\
\text { reduction of 1.3 ton per employee. (Telia) }\end{array}$ \\
\hline $\begin{array}{l}\text { Videoconferencing, } \\
\text { [30] }\end{array}$ & $\begin{array}{l}\text { 3 tonnes CO2 reduction per employee and year in } \\
\text { 2006-2010 (Cisco) }\end{array}$ \\
\hline $\begin{array}{l}\text { Videoconference } \\
\text { potential, [14] }\end{array}$ & $\begin{array}{l}\text { Assumes that one-third of business aviation trips } \\
\text { could be replaced with videoconference meetings. }\end{array}$ \\
\hline $\begin{array}{l}\text { Videoconferencing, } \\
\text { other sources }\end{array}$ & $\begin{array}{l}11 \text { other references for videoconferencing from } \\
\text { company sources such as AXA, Deutsche Telecom, } \\
\text { British Telecom, and AT\&T have been investigated } \\
\text { but cannot be described due to lack of space. }\end{array}$ \\
\hline $\begin{array}{l}\text { Telecommuting, } \\
\text { [31] }\end{array}$ & $\begin{array}{l}3,4 \text { ktonnes CO2 reduced commuting mainly in } \\
\text { Japan by encouraging 330000 employees to } \\
\text { telecommute and have online meetings (Panasonic) }\end{array}$ \\
\hline $\begin{array}{l}\text { Telecommuting, } \\
\text { [32] }\end{array}$ & $\begin{array}{l}175 \text { million commuted miles avoided annually for } \\
130000 \text { employees in USA (AT\&T) }\end{array}$ \\
\hline $\begin{array}{l}\text { Teleworking, } \\
\text { [33],[34] }\end{array}$ & $\begin{array}{l}\text { 100 million miles annually avoided airplane travel, } \\
\text { (17ktonnes CO2 annually) for 80000 employees } \\
\text { USA/globally (Microsoft) }\end{array}$ \\
\hline Teleworking, [35] & $\begin{array}{l}\text { Reduction in annual vehicle travel miles by 0.8\% } \\
\text { or less 1988-1998 in a nationwide US study. }\end{array}$ \\
\hline Telepresence, [12] & $\begin{array}{l}\text { 28000 km flight distance reduction potential if 895 } \\
\text { oversees travels are avoided by the 1.1 \% of the } \\
\text { companies in Korea having telepresence equipment }\end{array}$ \\
\hline $\begin{array}{l}\text { Teleworking } \\
\text { potential, [14] }\end{array}$ & $\begin{array}{l}\text { Assumes that decentralized workplaces are used by } \\
15 \% \text { of employees who have jobs suitable for } \\
\text { telework, and that their commuting emissions are } \\
\text { reduced by at least 50\%. }\end{array}$ \\
\hline
\end{tabular}

\section{E. Smart travel}

Within the travel category, the ICT solutions are used for optimization of routes, variable speed applications and public travels. As an example, there are crowd sourcing applications that show traffic congestion, inform about different travel modes and routes and which also support sharing of vehicles. The potential for smart parking is assumed to form part of the overall route optimization.

Smart public travel can lead to reduced private car travel. It includes smart ticket systems, bus/train arrival information, road tolls, etc. Note that this concept might include more than ICT. The fleet car management is similar to the ICT solutions for smart transport, but here the emissions are due to car transports rather than goods transports on trucks. 
TABLE VII. BACKGROUND DATA FOR SMART TRAVEL

\begin{tabular}{|c|c|}
\hline $\begin{array}{l}\text { Route optimization } \\
\text { for private car, [36] }\end{array}$ & $\begin{array}{l}\text { Two implementations for Yokohama corresponding } \\
\text { to } 8.7 \% \text { and } 17 \% \mathrm{CO}_{2} \text { reductions. } 17 \% \text { reduction } \\
\text { corresponded to } 20 \% \text { time savings (Nissan). }\end{array}$ \\
\hline $\begin{array}{l}\text { Route optimization, } \\
\text { [12] }\end{array}$ & $\begin{array}{l}11.8 \% \text { estimated fuel consumption reduction in } \\
\text { Seoul, Korea }\end{array}$ \\
\hline $\begin{array}{l}\text { Fleet management, } \\
\text { electronic ticketing, } \\
\text { [37] }\end{array}$ & $\begin{array}{l}2 \text { ktonnes CO2e reduction for } 1928 \text { buses in } \\
\text { Curitiba if bus operation efficiency increases by } \\
1 \%\end{array}$ \\
\hline $\begin{array}{l}\text { Bus information } \\
\text { system, [12] }\end{array}$ & $\begin{array}{l}\text { More people use bus and leave car, } 21 \% \text { of } \\
\text { compound annual growth rate }\end{array}$ \\
\hline $\begin{array}{l}\text { Real time } \\
\text { information } \\
\text { potential, [12] }\end{array}$ & $\begin{array}{l}0.25 \text { tonnes CO2e expected to be reduced in } 2011 \\
\text { as more people use bus instead of car. At } 21 \% \text { of } \\
\text { compound annual growth rate this gives a Korean } \\
\text { reduction of } 1.4 \text { million tonnes CO2e by } 2020\end{array}$ \\
\hline $\begin{array}{l}\text { Internet based travel } \\
\text { planner, [38] }\end{array}$ & $\begin{array}{l}51 \% \text { of current car users declare shift to public } \\
\text { transport but only } 1 \% \text { will totally abandon cars in } \\
\text { favor of public transports }\end{array}$ \\
\hline $\begin{array}{l}\text { Speed adaptation } \\
\text { [28] }\end{array}$ & Fuel reduction by $8 \%$ in UK study \\
\hline $\begin{array}{l}\text { Smart car travel } \\
\text { solutions potential, } \\
\text { [13] }\end{array}$ & $\begin{array}{l}\text { According to simulation, ICT could avoid } 10-19 \% \\
\text { of the expected future (2020) car traffic. Note } 2020 \\
\text { traffic expected to increase compared to } 2000 .\end{array}$ \\
\hline $\begin{array}{l}\text { Virtual mobility } \\
\text { potential, [13] }\end{array}$ & $\begin{array}{l}6-8 \% \text { of the future (2020) passenger transport level } \\
\text { estimated to be avoided due to virtual mobility }\end{array}$ \\
\hline $\begin{array}{l}\text { Personalized public } \\
\text { travel potential, [14] }\end{array}$ & $\begin{array}{l}\text { Assumes that wireless broadband-facilitated } \\
\text { personalized public transport could move } 10 \% \text { of } \\
\text { Australian car commuters to public transports }\end{array}$ \\
\hline $\begin{array}{l}\text { Public transport } \\
\text { information } \\
\text { potential, [14] }\end{array}$ & $\begin{array}{l}\text { Urban public transport trips increased both in } \\
\text { overall terms ( } 10 \% \text { increase in passenger distance } \\
\text { travelled) and as share of overall passenger task } \\
\text { (from } 9.2 \% \text { to } 10.9 \%) \text {. Fuel price increase is part of } \\
\text { the explanation, but ICT innovations as well. }\end{array}$ \\
\hline
\end{tabular}

\section{F. Smart services}

Smart services is a category that includes solutions for ecommerce or e-business, sometimes defined as the process of buying and selling products or services online. It also includes the shift from products to services, for instance ICT solutions used for car pools and renting of machines, clothes and other things. Sometimes the smart services and smart shopping are grouped together with solutions for banking, entertainment and government. However, that is not done here.

Few references have been found that includes actual GHG reduction emissions data for smart services.

\section{TABLE VIII. BACKGROUND DATA FOR SMART SERVICES}

\begin{tabular}{|l|l|}
\hline $\begin{array}{l}\text { e-commerce, } \\
{[12]}\end{array}$ & $\begin{array}{l}\text { Estimated reduction of -3 billion kilometer private car } \\
\text { travel and -0.63 billion kWh due to less cooling, heating } \\
\text { and lightning. This results in a reduction of 0.72 million } \\
\text { tonnes CO2e in the travel/transport sector and 0.29 } \\
\text { million tonnes CO2e in the building sector in Korea } 2011 .\end{array}$ \\
\hline $\begin{array}{l}\text { e-commerce } \\
\text { potential, [20] }\end{array}$ & $\begin{array}{l}\text { Under the most optimistic assumptions made with regard } \\
\text { to all uncertain model parameters - ICT could reduce the } \\
\text { increase in freight transport by roughly 25\% until 2020. }\end{array}$ \\
\hline $\begin{array}{l}\text { e-commerce, } \\
\text { [39],[40],[41] }\end{array}$ & $\begin{array}{l}\text { 3\% reduction of total GHG emissions in Japan as a } \\
\text { potential for 2010. Estimate including both business-to- } \\
\text { business and private e-commerce, in 2003 and 2008. }\end{array}$ \\
\hline $\begin{array}{l}\text { Products-to- } \\
\text { services, [8] }\end{array}$ & $\begin{array}{l}\text { Reductions between 3.75-37.5\% in industrial production } \\
\text { in EU 2020. Reductions due to ICT-based products-to- } \\
\text { service shift estimated to be between 0\% and 10\%. }\end{array}$ \\
\hline
\end{tabular}

\section{G. Agriculture and land use}

Smart agriculture is about ICT solutions for soil monitoring, weather forecasting, and smart watering systems etc. Included are also solutions for managing large live stocks and monitoring equipment, reducing overlaps when harvesting and getting data to pro-actively diagnose problems and coordinate fleets.

Although interesting, ICT solutions for agriculture and land use have not been a focus of this study due to lack of time. However, to get a more complete view on ICTs potential to reduce GHG emissions, and to understand how overall results compare with particularly the SMARTer 2020 report [7], the results for agriculture and land use from [7] have been used. The reader should know that these results are used as is without in depth review of their quality. Thus, all results are presented with these assumed reductions included as well as excluded.

\section{H. Mapping between ICT solutions and end-use sectors}

To understand how the ICT solutions apply to the different end-use sectors a mapping is performed as described in III.A. As an example, smart grid improvements will lead to emissions reductions in all electricity using sectors, affecting mainly industry and buildings, but to some extent also other sectors (transport and travels). Figure 3 shows the mapping between ICT solutions and main affected sectors. However, the applied model is considering all interrelationships between the ICT solutions and the sectors.

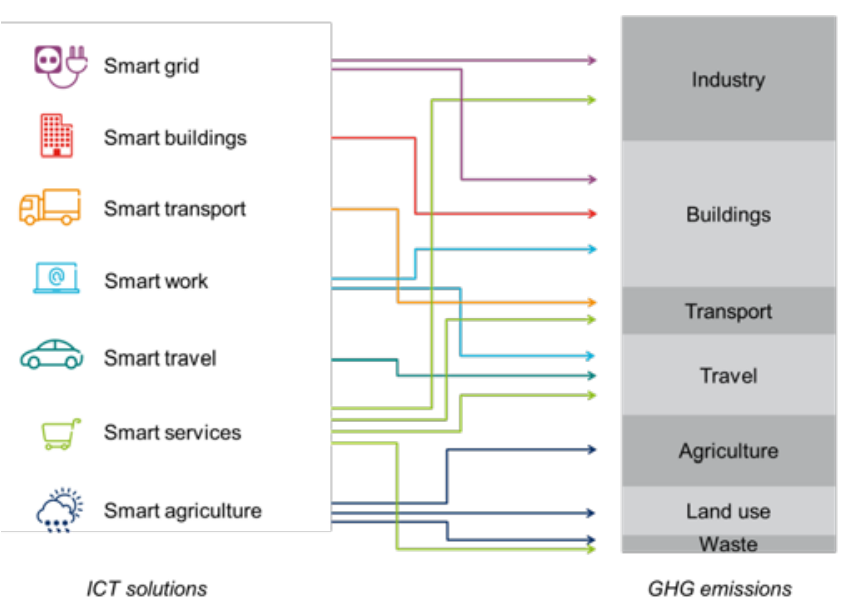

Figure 3 Mapping between ICT solutions categories and the GHG emission categories as defined by IPCC.

\section{EMISSION REDUCTION POTENTIAL IN 2030}

\section{A. The scenarios}

This study estimates the GHG emissions reduction potential for two scenarios: the Medium Reduction Potential Scenario (MRPS) and the High Reduction Potential Scenario (HRPS). MRPS is representing the median of the potentials shown in the references, with some modifications as described in section V.B. HRPS corresponds to the highest potential from the references which is considered as credible and reasonable to apply as a global scale average - for instance the high potential 
may represent the energy savings achieved by the best energy savers among smart meter customers.

\section{B. The potential GHG emissions reductions per ICT solution}

Table IX shows the highest potential claimed in the background data (column 2) as well as the potentials used for the explored scenarios, MRPS and HRPS (column 3). The percentage values represent overall reductions by 2030 compared to the 2030 baseline.

TABLE IX. REDUCTION POTENTIALS FROM REFERENCES AND POTENTIALS USED FOR THE ICT SOLUTIONS

\begin{tabular}{|c|c|c|c|}
\hline $\begin{array}{l}\text { Enabling ICT } \\
\text { solutions }\end{array}$ & $\begin{array}{c}\text { Ref. } \\
\text { high } \\
\%\end{array}$ & $\begin{array}{c}\text { MRPS/ } \\
\text { HRPS } \\
\% *\end{array}$ & $\begin{array}{l}\text { Addressable emissions } \\
\% \text { of emissions from } \\
\text { (sub)sector }\end{array}$ \\
\hline $\begin{array}{l}\text { Smart grids: } \\
\text { Smart metering }\end{array}$ & 10 & $5 / 10$ & $\begin{array}{l}\text { Residential buildings energy: } \\
57 \% \text { of Buildings sector }\end{array}$ \\
\hline $\begin{array}{l}\text { Power grid } \\
\text { optimization }\end{array}$ & 60 & $15 / 30$ & $\begin{array}{l}\text { Transmission and distribution } \\
\text { electricity losses: } \\
8 \% \text { of electricity, } 2 \% \text { of } \\
\text { global emissions }\end{array}$ \\
\hline $\begin{array}{l}\text { Facilitating renewable } \\
\text { energy sources }\end{array}$ & 9 & $2 / 7$ & $\begin{array}{l}\text { Electricity production: } \\
25 \% \text { of global emissions }\end{array}$ \\
\hline $\begin{array}{l}\text { Smart buildings: } \\
\text { Smart building } \\
\text { solutions for offices, } \\
\text { stores, hotels, schools, } \\
\text { etc. }\end{array}$ & 40 & $10 / 15$ & $\begin{array}{l}\text { Energy consumption in } \\
\text { offices, stores, hotels, } \\
\text { schools, etc.: } \\
31 \% \text { of Buildings sector }\end{array}$ \\
\hline $\begin{array}{l}\text { Smart building } \\
\text { solutions for } \\
\text { healthcare, food stores } \\
\text { and services, etc. }\end{array}$ & 17 & $3 / 5$ & $\begin{array}{l}\text { Energy consumption in } \\
\text { healthcare, food stores and } \\
\text { services, etc.: } \\
9 \% \text { of Buildings sector }\end{array}$ \\
\hline $\begin{array}{l}\text { Smart transports: } \\
\text { Route optimization, } \\
\text { fleet management }\end{array}$ & 23 & $10 / 20$ & $\begin{array}{l}\text { All road transport: } \\
58 \% \text { of Transport sector }\end{array}$ \\
\hline $\begin{array}{l}\text { Facilitating the choice } \\
\text { of transport mode with } \\
\text { help of ICT }\end{array}$ & 50 & $5 / 10$ & $\begin{array}{l}\text { Shift from air to train/ship, } \\
10 \% \text { of Transport sector }\end{array}$ \\
\hline $\begin{array}{l}\text { Smart work: } \\
\text { Telemeetings, etc. }\end{array}$ & 60 & $20 / 30$ & $\begin{array}{l}\text { Air business travel: } \\
7 \% \text { of Travel sector }\end{array}$ \\
\hline Telemeetings, etc. & 50 & $10 / 20$ & $\begin{array}{l}\text { Car business travel: } \\
12 \% \text { of Travel sector }\end{array}$ \\
\hline Telemeetings, etc. & - & $\begin{array}{c}12.5 / \\
25\end{array}$ & $\begin{array}{l}\text { Hotels used for business, } \\
1.6 \% \text { of Building sector }\end{array}$ \\
\hline $\begin{array}{l}\text { Reduced office space, } \\
\text { due to ICT }\end{array}$ & 25 & $10 / 20$ & $\begin{array}{l}\text { Office buildings: } \\
7 \% \text { of Buildings sector }\end{array}$ \\
\hline Teleworking & 50 & $15 / 30$ & $\begin{array}{l}25 \% \text { of private car travel is } \\
\text { allocated to employees who } \\
\text { could work from home to } \\
\text { some extent: } \\
17.5 \% \text { of Travel sector }\end{array}$ \\
\hline $\begin{array}{l}\text { Smart travel: } \\
\text { Smart public travel }\end{array}$ & 10 & $5 / 10$ & $\begin{array}{l}\text { Private car travel: } \\
35 \% \text { of Travel sector }\end{array}$ \\
\hline Fleet car management & 23 & $8 / 15$ & $\begin{array}{l}\text { Commercial car travel: } \\
12 \% \text { of Travel sector }\end{array}$ \\
\hline Route optimization & 17 & $5 / 10$ & $\begin{array}{l}\text { All road travel: } \\
82 \% \text { of Travel sector }\end{array}$ \\
\hline $\begin{array}{l}\text { Smart services: } \\
\text { e-commerce solutions, } \\
\text { products-to- services }\end{array}$ & 10 & $5 / 10$ & $\begin{array}{l}\text { All transports and industry: } \\
100 \% \text { of Transport sector } \\
100 \% \text { of Industry sector }\end{array}$ \\
\hline $\begin{array}{l}\text { Smart agriculture } \\
\text { incl. land use: }\end{array}$ & 13 & $7 / 13$ & $\begin{array}{l}\text { Agriculture incl land use: } \\
100 \% \text { of Agriculture sector }\end{array}$ \\
\hline
\end{tabular}

Table IX (column 4) shows the relative addressable emissions for different ICT solutions expressed as percentage of the sector emissions. Absolute addressable emissions for the ICT solutions are calculated by multiplying those with the absolute sector emissions of table II. The absolute addressable emissions are then multiplied by the scenario potentials (column 3) to calculate the reduction potential per ICT solution. In this calculation double-counting between solutions addressing the same emissions are carefully avoided within and between sector

To understand how the reduction in GHG emissions from each category impacts overall emissions, the reduction of each category was divided by the total global GHG emissions in 2030 (see Table X). As an example, ICT solutions for smart grid include smart metering, power grid optimization and facilitating renewables (Table IX). The potentials of these are multiplied by their addressable emissions while avoiding double-counting to calculate the potential of the sector. This potential is then divided by the 2030 baseline for overall global GHG emissions (Table X).

TABLE X. INDIVIDUAL REDUCTION POTENTIALS FOR 2030 PER ICT SOLUTION CATEGORY

\begin{tabular}{|l|c|c|}
\hline ICT solution category & HRS & MRS \\
\hline Smart grid & $3.9 \%$ & $1.6 \%$ \\
\hline Smart buildings & $1.4 \%$ & $0.9 \%$ \\
\hline Smart transport & $1.1 \%$ & $0.6 \%$ \\
\hline Smart travel & $1.9 \%$ & $0.9 \%$ \\
\hline Smart work & $1.9 \%$ & $0.9 \%$ \\
\hline Smart services & $3.2 \%$ & $1.6 \%$ \\
\hline $\begin{array}{l}\text { Smart agriculture and land use } \\
\text { (inherited from SMARTer } \\
\text { 2020) }\end{array}$ & $2.9 \%$ & $1.3 \%$ \\
\hline
\end{tabular}

Based on MRPS, the highest potentials for the different ICT solution categories were estimated to $1-4 \%$ of the overall global GHG emissions. The smart grid solution category has the largest potential. Also worth noting is that the inherited potential for agriculture and land use is relatively high.

The values in Table $\mathrm{X}$ show the potential for each ICT solution category by its own, without considering solutions from other categories addressing the same emissions. Hence, if added together the resulting potential will be too high due to double-counting effects. Total values without double-counting are given in section V.D and represent overall reductions by 2030 compared to the 2030 baseline.

\section{Inclusion and exclusion of ICT solutions}

For all solution categories introduced in section IV, and potentials according to section V.B, it is necessary to define the boundaries applied in terms of included and excluded ICT solutions etc.

Smart Grid: ICT is a facilitator for the introduction of renewable energy sources, but it is not obvious to what extent reductions could be claimed by ICT. This study applies the potentials suggested in [13], including integration of small 
scale renewable energy sources, but not general increase in the use of wind power.

Smart Buildings: Reduction potentials for buildings with critical activities, like healthcare and food storage, have been assumed to be lower and the estimated figures have been set to one third of the reduction potential estimated for other buildings.

Smart Transports: For route optimizations, the reduction potentials of company-owned cars and small trucks utilized for transport purposes have been allocated to Smart Travel due to the way companies report data. Further, the road transport reductions do not include emissions from buses because this is representing only a minor part of total emissions [42]. For fleet management, no figures were found on reduced fuel use due to shorter harbour times and better packed ships, therefore such reductions are not included. ICT based solutions are already widely adopted for both route optimization and fleet management. In other words, the estimated reduction potential has to some extent already been realized and is embedded in the baseline. Therefore, we have used lower emission reduction potentials than indicated by the available data to take this into account.

For smart street lights, some data exists, for example in [43], but no reduction potential has been included for two main reasons. Firstly, smart street light projects often combine change of lamp type (e.g. into LED lights) and control through ICT, and reductions data does not distinguish between those. Secondly, it has not been possible to identify the emissions from streetlights within the total global GHG emissions.

This study also assumes that emissions from ship and train transports will not increase in spite of the shift to these transport modes, assuming that efficiency gains of these transports will compensate for their increased use.

For the shift from air transports to train and ship, the potentials are based on Ericsson's own improvements in this area [44]. It can be discussed to what extent ICT is enabling these kind of changes, but it is believed ICT plays an important role by enabling better control of the freight, thereby increasing the probability for changes in transport mode. It is assumed that the large GHG emission reductions experienced by Ericsson (emission have roughly halved) due to the change of transport mode are too high to be used for all freights globally. Therefore a much lower potential has been set (5-10\%).

Potentials related to co-optimization of different transport modes have not been investigated.

Smart work: For impacts related to hotels, it is estimated that $25 \%$ of the business related hotel nights can be avoided, which is about half of the total number of hotel nights spent [45]-[46].

The need for office space could be reduced due to dematerializations including fewer bookshelves, thinner screens, less paper, no fixed phones, fewer printers and so on, but it is assumed that this potential has to a large extent already been realized. However, some potential still remains in terms of flexi-work spaces, open offices, etc., especially in the global perspective.
For commuting, it is considered that half of the emissions related to private car travel emerge from commuting [58]. Furthermore, our previous research [29] indicates that approximately $40 \%$ of workers have tasks that could be performed from home occasionally, and an Australian study [14] declares that about 55\% of Australian jobs are amendable to telework. Also, these travellers are more likely to be car commuters than the average employee [47]. Based on these sources it is assumed that 25\% of the GHG emissions for private car travels is allocated to commuters that could work from home to some extent. For these emissions a reduction protential of 15\% (MRPS) and 30\% (HRPS) was used

Smart travel: In our scenarios the potentials for fleet management for travels are set somewhat lower than for transports as it is likely that car fleets from different companies and sectors are not co-optimized as efficiently as the fleets within truck companies. Also the route optimization potential is set somewhat lower compared to the references listed, as the figure is applied globally and for both urban and rural travel although it is assumed that main reductions occur in urban areas and for short distance trips - the conditions applicable for the reference case studies.

Smart services: The potentials used for HRPS correspond to a total of 3\% of all GHG emissions, which is the same figure as in [39]-[41] and [8]. It is considered that smart services is already widely adopted for some businesses, e.g. for the media and music industry.

Agriculture and land use: Potentials for agriculture and land use were not part of the data collection. Instead, reductions in GHG emissions were included based on GeSI's SMARTer2020 report [7]. In that report a total of 12.4 Gtonnes $\mathrm{CO}_{2} \mathrm{e}$ was reported for agriculture, while IPCC reports only about 7 Gtonnes $\mathrm{CO}_{2} \mathrm{e}$ for agriculture [48]. If adding the GHG emissions from land use and waste to the agriculture emissions in the IPCC report, a total of 12.3 Gtonnes $\mathrm{CO}_{2} \mathrm{e}$ is estimated for 2020. It is thus assumed that the SMARTer 2020 value includes also impact from land use (which is to high extent related to agriculture and clearing of forests to grow crops) and waste (partly relates to organic waste from agriculture and the food chain). No emission reductions for forestry are included.

The SMARTer2020 figure has been used as is. However, some of the potential may be due to local electronic solutions that should not be included if a deeper analysis of this sector was performed, see [9].

\section{Estimated GHG emission reductions per scenario}

Based on the potentials in Table IX, and the emissions per sector in Table II, the estimated reduction potentials were calculated for the two scenarios. For HRPS a potential GHG emissions reduction of about 8 Gtonnes $\mathrm{CO}_{2} \mathrm{e}$ was estimated for the investigated ICT solutions. If also agriculture is added, based on the SMARTer 2020 [7] estimate, the value increases to about 10 Gtonnes. These potentials correspond to $12.4 \%$ and $15.3 \%$ of the estimated global GHG emissions in 2030 (63.5 Gtonnes $\mathrm{CO}_{2} \mathrm{e}$ ) respectively. In the MRPS a potential of 4 Gtonnes $\mathrm{CO}_{2} \mathrm{e}$ for 2030 was achieved without considering the agriculture sector, corresponding to $6.1 \%$ of the global GHG emissions. When including also the potential in the agriculture 
sector, the reduction becomes 5 Gtonnes $\mathrm{CO}_{2} \mathrm{e}$ or $7.4 \%$ of the global GHG emissions.

As shown in Figure 4, these potentials include some embodied emissions reductions in, for instance, infrastructure and manufacturing. Particularly, potentials are included due to reductions in new building construction and road infrastructure extension and maintenance due to less traffic. Without these embodied emissions, the HRPS potential without agriculture reduces to $10.7 \%$ and MRPS becomes 5.3\%, see Figure 4

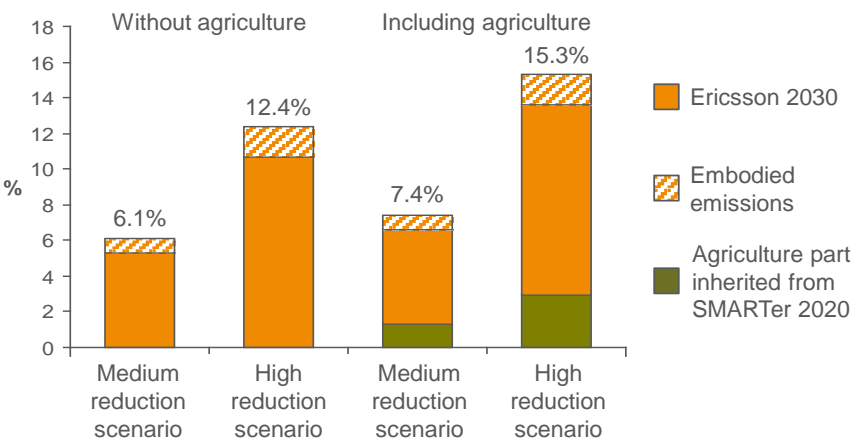

Figure 4 Global reduction potentials 2030 due to assessed ICT solutions relative to 2030 baseline of 63.5 Gtonnes CO2e.

\section{DISCUSSION}

\section{A. The approach}

It is clear that a study of this kind is associated with high uncertainties, which is the reason why different scenarios were defined. The high uncertainty applies to both the medium and the high reduction potential scenarios. However, it is not regarded as meaningful (or possible) to quantify the uncertainties associated with this kind of study. Uncertainty sources include the many assumptions needed, the limited availability of case studies and the use of scaling from individual case studies to global potentials. On top of this the uncertainties related to future development are added.

The strength of the approach is that it is based on real achievements by ICT today, and that it tries to be as transparent as possible regarding data, assumptions and uncertainties within the available number of pages.

As published data on achieved reductions often do not consider the footprint of ICT itself, the footprint of the ICT solution has to be calculated and extracted from the positive effect investigated in this paper.

\section{B. Realization of the potential}

The GHG reduction potentials set in this study are based on the limited number of case studies available at the time of data collection. Reduction potentials can - and should - be amended as more references relating to actual emission savings becomes available. Particularly, ICT solutions for agriculture and smart consumer and services should be more thoroughly investigated. Furthermore, the potentials and the addressable emissions could be detailed in order to set more well-founded reduction potentials for individual services. For instance, a better understanding of how e-learning affects travelling requires that the share of travels related to training and education is known.
The potentials set for HRPS are often somewhat lower than found in specific references, taking into account that they should be possible to realize globally. For instance some high reduction potentials found for videoconferencing may not be scalable if the baseline represents very intense travelling.

As described in section III, this paper uses an average value from IPCC's basic scenarios as a baseline for the overall GHG emissions 2030. It is assumed that IPCC has taken some general technology improvements into account when developing their basic scenarios [2] but this could in our case only lead to a partial double-counting of the potential related to facilitated integration of small-scale renewable energy in our scenarios. Even in the mitigation scenarios [1], which have not been used in this study, non-technical factors such as life style changes are not considered. Such factors are important mechanisms for several ICT solutions [48]. Future studies, could combine the results in this study with IPCC's mitigation scenarios (a 2030 reduction of 5-31 Gtonnes globally, or 7\%$45 \%$ ) making sure to avoid double-counting of potentials.

Reduction potentials are applied on forecasted 2030 emissions which are higher than today's emissions. Hence, in absolute numbers there might not be a reduction compared to today. Rather, ICT can slow down the expected increase.

The GHG reductions potential forecasted in this paper is to be seen as a potential for the assessed solutions which is reachable based on the technology available today. Additional opportunities for reductions may exist due to new technology or new use of existing technology. On the other hand, the reductions potential forecasted represent a technology potential only. As most input data emerge from small scale projects, often driven due to cost/energy or GHG saving initiatives, it seems reasonable to assume that realization of global potentials demands involvement of policy makers, companies and the general public, through mechanisms such as policy measures, and collaborations between industry and the public sector.

This study is focused on ICTs (positive) effects in other sectors, while not evaluating if ICT might also have negative effects beyond its direct footprint. For instance, rebound, the risk that some efficiency gains are offset by increased consumption, is not studied in this paper but may impact the actual reductions considerably. As an example, smart services which can reduce travel and transport may also lead to increased shopping due to price reductions and improved accessibility. E-shopping may also cause transports due to return of goods. Consumer behavior analysis is needed to increase awareness and mitigate rebound effects.

\section{Comparison to GeSI SMARTer2020}

In this study we estimate that the assessed ICT solutions enable a global GHG reduction potential of 15.3\% for 2030 in HRPS including also the potential for agriculture sector. The often cited SMARTer2020 report by GeSI [7], sees a higher potential of $16.5 \%$ already for 2020 . See figure 5 .

As discussed in [9], there are other differences to consider if comparing these estimates Firstly, by removing the doublecounting between categories from the SMARTer2020 results the potential reduces to about 15\% (second bar in Figure 5). Secondly, potential reductions in SMARTer2020 include local, 
not ICT-based, electronic solutions in building design, manufacturing systems and electrical motors as well as largescale renewable electricity production. If the potential from such solutions are removed the resulting potential becomes 11\% (third bar in Figure 5). Also, there are other ICT solutions, like eco-driving and minimization of packaging where ICTs role could be discussed, but they have not been excluded in the SMARTer 2020 re-calculations in Figure 5.

Considering the 2020 time frame, small-scale renewable integration in buildings is not likely to happen on a large scale (though included for SMARTer2020 in Figure 5). However, in our scenarios, applying a 2030 perspective, the small-scale renewable integration potential has been included.

In the Ericsson scenarios, reductions in life cycle stages other than the use stage, have also been included, which was not undertaken in the SMARTer2020 report.

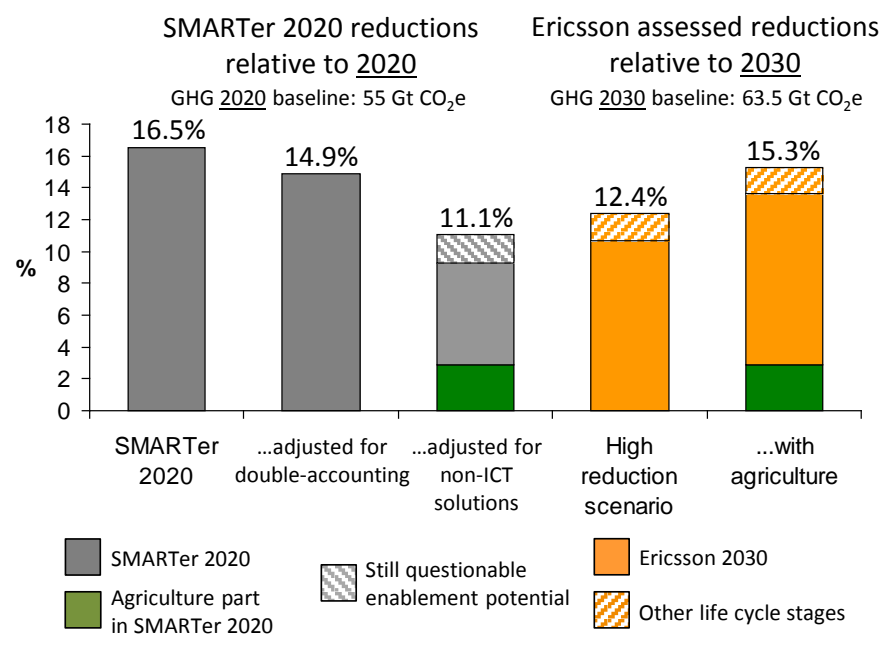

Figure 5 Comparison between GeSI’s SMARTer2020 study [7] and this study.

\section{CONCLUSIONS}

The following conclusions apply:

- A total GHG emissions reduction of 8 Gtonnes $\mathrm{CO}_{2} \mathrm{e}$ due to the studied ICT solutions (excluding agriculture) is calculated for the high reduction potential scenario (HRPS) for 2030. This corresponds to about $12 \%$ of the global GHG emissions in 2030. If the potential for agriculture is included the reductions are 10 Gtonnes $\mathrm{CO}_{2} \mathrm{e}$ or about $15 \%$ of the global GHG emissions in 2030.

- In the medium reduction potential scenario (MRPS) a GHG emissions reduction of 4 Gtonnes $\mathrm{CO}_{2} \mathrm{e}$ for 2030 was achieved without including any potential in the agriculture sector. That corresponds to about $6 \%$ of the global GHG emissions. If the potential in the agriculture sector is added the reduction becomes about 5 Gtonnes or or $8 \%$ of the global GHG emissions.

- The 2030 potential for the different ICT solution categories to reduce the global GHG emissions lies around $1-4 \%$.
- $\quad$ The study confirms that ICT has a substantial potential to mitigate climate change which could be leveraged by society.

\section{ACKNOWLEDGMENT}

The authors wish to thank Nina Lövehagen, former Ericsson employee, for her substantial and highly valued contribution.

\section{REFERENCES}

[1] IPCC, "Climate change 2014: Synthesis report. Summary for policymakers". Fifth Assessment Report of the Intergovernmental Panel on Climate Change (IPCC) [Core Writing Team editor, Pachauri, P.K and Meyer, L.]. IPCC, Geneva, Switzerland, 2014, 39 pp.

[2] IPCC, "Climate change 2007: Synthesis report. Contribution of Working Groups I, II and III to the Fourth Assessment Report of the Intergovernmental Panel on Climate Change" [Core Writing Team, Pachauri, R.K and Reisinger, A. (eds.)]. IPCC, Geneva, Switzerland, 2007, 104 pp.

[3] T. Herzog, "World greenhouse gas emissions in 2000", World Resource Institute (WRI), 2005, Available on line at www.wri.org/publication/navigating-the-numbers .

[4] World Resource Institute , "World greenhouse gas emissions in 2005", Available at http://www.wri.org/resources/charts-graphs/worldgreenhouse-gas-emissions-2005

[5] World Resource Institute , CAIT 2.0 WRI's Climate data explorer available through:

http://www.wri.org/our-work/project/cait-climate-data-explorer

Tool available at:

http://cait2.wri.org/wri\#Country GHG Emissions?indicator=Total GHG Emissions Excluding LUCF\&indicator=Total GHG Emissions Including LUCF\&year $=2010 \&$ chartType $=$ geo

[6] European Commission Joint research Center, EDGAR - emission database for global atmospheric research, version 4.0, available at http://edgar.jrc.ec.europa.eu/

[7] GeSI, "SMARTer 2020: The role of ICT in driving a sustainable future", 2013.

[8] L. Erdmann, L. Hilty, J. Goodman, and P. Arnfalk, "The future impact of ICTs on environmental sustainability”, Technical report series. EUR 21384 EN. European Commission and Institute for Prospective Technological Studies report, 2004

[9] J. Malmodin, P. Bergmark, N. Lövehagen, M. Ercan, and A. Bondesson, "Considerations for macro-level studies of ICT's enablement potential”, ICT4S-14, 2014.

[10] BC Hydro, "Smart metering \& infrastructure program business case", 2011/2012? . http://www.bchydro.com/content/dam/BCHydro/customerportal/documents/projects/smart-metering/smi-program-businesscase.pdf accessed October 2014

[11] B. Foster and S. Mazur-Stommen, "Results from recent real-time feedback studies", American Council for an Energy-Efficient Economy, Report number B122, 2012.

[12] ITU, "The case of Korea: the quantification of GHG reduction effects achieved by ICTs”. Geneva, 2013.

[13] L:M. Hilty, P. Arnfalk, L. Erdmann, J. Goodman, M. Lehmann, and P.A. Wäger, "The relevance of information and communication technologies for environmental sustainability - A prospective simulation study", Environmental Modelling \& Software 21 (2006) 1618-1629, 2006

[14] K. Mallon, J. Wormworth, C.Scott, J. Abs, J. Bohm, "Connecting with a low-carbon future”, Report from Telstra and Climate Risk. ISBN 978-09804343-9-2, 2014.

[15] Lonmark, "Case study: German building slashed energy costs with Lonworks networks”, accessed October 2014. http://www.lonmark.org/connection/case_studies/documents/Germany_ BalancedOfficeBuilding.pdf

[16] Lonmark, Lonmark magazine International edition. Vol. 3, Issue 4, October 2007. Accessed Oct 2014 at 
http://www.Imimagazine.com/downloads/LM_Magazine_international 12.pdf

[17] S. Narayanan, R. Taylor, S. Yuan, Y. Lin, S. Bengea, D. Vrabie, S. Killough, T. Kuruganti, W. Manges, and K. Woodworth, "A Wireless platform for energy efficient building control retrofits”, ESTCP Project EW-200938, 2012.

[18] R. Mahdavi and W. Tschudi, "Wireless sensor network for improving the energy efficiency of data centers", 2012,

http://www.gsa.gov/graphics/pbs/wireless-sensor-network-final-fullreport.pdf , accessed July 2013

[19] M. Buttazoni, "Potential global CO2 emission reductions from ICT use: Identifying and assessing the opportunities to reduce the first billion tonnes of CO2 emissions”. Ecofys Italy Srl. Solna, Sweden: World Wildlife Fund Sweden, 2008.

[20] M. Ahmadi Achachlouei and L. Hilty, "Modeling the effects of ICT on environmental sustainability: revisiting a system dynamics mode developed for the European Commission”. In: Hilty, L.M.; Aebischer, B. (ed.), ICT Innovations for Sustainability (pp. 449-474). Switzerland: Springer International Publishing Advances in Intelligent Systems and Computing, 2015. http://dx.doi.org/10.1007/978-3-319-09228-7_27

[21] F. Berkhout, and J. Hertin, "Impacts of information and communication technologies on environmental sustainability: speculations and evidence”, Report to the OECD. University of Sussex. May 25, 2001.

[22] P. Cosar-Jorda, R.A.Buswell, and V. Mitchell, "Estimating the potential reductions in energy demand through efficiency, control and lifestyle change in a real home", Proceedings of Future Build, Bath University, 46 September 2013, pp. 135 - 144.

[23] Verizon, "Network fleet drives, quick payback at Eastern municipal water district”, case study, 2013http://info.networkfleet.com/rs/networkfleet/images/CAN001_Eastern_Municipal_Water_District.pdf , accessed October 2014.

[24] Vodafone/Accenture, "Carbon connections: quantifying mobile's role in tackling climate change”, 2009, accessed October 2014, http://www.accenture.com/SiteCollectionDocuments/Accenture Carbon _Connections_Quantifying_Mobiles_Role_in_Tackling_Climate_Chang e.pdf

[25] DHL, "DHL and Blue Dart steer India’s logistics in a new direction with the launch of Smart Truck", 2011, http://www.dhl.com/en/press/releases/releases 2011/group/081011.html, accessed July 2013

[26] Deutsche Telekom, “Climate-friendly mobility”, 2012, http://www.crreport.telekom.com/site12/climate-environment/climate-friendlymobility\#atn-1410-1516, accessed June 2013

[27] Vodafone,” Vodafone Global M2M - Mic-O-Data”, case study, 2012, http://business.vodafone.nl/Vodafone/wg30/pdf/case study mic-odata.pdf accessed October 2014

[28] W.R. Black, and M. van Geenhuizen, "ICT innovation and sustainability of the transport sector”, EJTIR, 6, no. 1 2006, pp. 39-60

[29] J. Malmodin, D. Lundén, N. Lövehagen, "Methodology for life cycle based assessments of the $\mathrm{CO}_{2}$ reduction potential of ICT services", Proceedings of the International Symposium on Sustainable Systems and Technology, Washington, USA, May 16-19, 2010.

[30] Cisco, CSR reports from 2006-2011. Available at http://www.cisco.com, accessed October 2014.2 (For instance: http://www.cisco.com/web/about/ac227/csr2011/docs/CSR2011_environ ment.pdf)

[31] Panasonic, “Eco-ideas report 2012”, 2012, p. 18, http://panasonic.net/eco/env data/back number/pdf/panasonic eiR2012 e.pdf , accessed June 2013

[32] AT\&T, “Telecommuting”, 2012. http://www.att.com/Common/about_us/files/csr_2012/telecommuting.pd f , accessed June 2013

[33] Microsoft technet, "Unified communications improves business outcomes, lowers costs, and enhances environmental sustainability, business case study”, 2010, http://technet.microsoft.com/enus/library/cc982178.aspx , accessed October 2014

[34] Microsoft, "Unified communications improves business outcomes, lowers costs, and enhances environmental sustainability”, 2011, http://technet.microsoft.com/en-us/library/cc982178.aspx, accessed June 2013

[35] S. Choo, P.L. Mokhtarian, and I. Salomon, "Does telecommuting reduce vehicle-miles traveled? An aggregate time series analysis for the U.S.”, Transportation, vol. 32, 2005, pp. 37-64.

[36] Nissan Motor Corporation, "SKY project to help reduce traffic accidents and ease congestion", presentation, 2013, slide 25 http://www.nissanglobal.com/EN/ENVIRONMENT/SOCIAL/ITS/PDF/SKYProj.pdf accessed Oct 2014.

[37] Ericsson, "Connected buses in Curitiba”, 2013. http://www.ericsson.com/res/thecompany/docs/corporateresponsibility/2011/curibita_final.pdf

[38] M. Bak, P. Borkowski, C. de Stasio, "Transferability of ICT solutions for improving co-modality in passenger transport”, Proceedings of the Transport Research Arena 2014, Paris, France.

[39] NTT, "Dynamic model for analysing environmental impacts caused by the ICT infrastructure in Japan”, Presented by NTT at the conference Environmental Assessment in the Information Society, 3-4 Dec 2003, Lausanne, Switzerland

[40] NTT, "Communications Group CSR Report 2008”, www.ntt.com/csr_e/report2008/index.html, accessed September 2009.

[41] NTT, “Transition and estimation of ICT energy impact assessment in Japan, macro economic input/output analysis”, NTT contribution to ETSI EE, 2008

[42] Svenska Bussbranschens Riksförbund, "Statistik om bussbranschen", Report in Swedish from Swedish Bus Organisation (Svenska Bussbranschens Riksförbund) 2013.

[43] H. Walraven, E-street initiative work package 2, market assessment and review of energy savings, report by Echelon on behalf of the E-Street project. July 31, 2006. Available at http://www.estreetlight.com/Documents/WP\%20FINAL/WP\%20D2.1\%20Market\%2 Oreview.pdf

[44] Ericsson's Sustainability and corporate responsibility reports 2008-2013, available on http://www.ericsson.com, accessed March 2015.

[45] S. Gössling and P. Upham, "Climate change and aviation: issues, challenges and solutions”, Earthscan climate, Routledge, ISBN: 9781844076208, 2009.

[46] Statistics Sweden and SIKA, "RES 2000: Den nationella reseundersökningen" (National Travel Survey (NTS) 2000), report in Swedish made by Statistics Sweden and SIKA, ISBN 91-89586-04-2, 2000.

[47] SLL, "Förstudie mobility managementåtgärder för Kista arbetsplatsområde och galleria”, Report in Swedish made by Stockholms läns landsting (SLL) - tillväxt och regionplanering, Trafikverket, SL och Länsstyrelsen i Stockholms län.LS 1102-0283. March 14, 2011.

[48] T. Barker, I. Bashmakov, A. Alharthi, M. Amann, L. Cifuentes, J. Drexhage, M. Duan, O. Edenhofer, B. Flannery, M. Grubb, M. Hoogwijk, F. I. Ibitoye, C. J. Jepma, W.A. Pizer, K. Yamaji, "Mitigation from a cross-sectoral perspective", in "Climate Change 2007: Mitigation. Contribution of Working Group III to the Fourth Assessment Report of the Intergovernmental Panel on Climate Change” [B. Metz, O.R. Davidson, P.R. Bosch, R. Dave, L.A. Meyer (eds)], Cambridge University Press, Cambridge, United Kingdom and New York, NY, USA, 2007. 